\title{
Inoculation methods and agressiveness of Macrophomina phaseolina isolates in cowpea
}

\author{
Erik Micael da Silva Souza ${ }^{1}$ (iD) Leonardo Aparecido Brandão da Silva ${ }^{1}$ (i) \\ Francisco Álef Carlos Pinto ${ }^{1}$ (D) Jerônimo Constantino Borel ${ }^{1}$ (i) \\ Alexandre Sandri Capucho ${ }^{1}$ (i) Francine Hiromi Ishikawa ${ }^{*}$ (i)
}

${ }^{1}$ Colegiado de Engenharia Agronômica, Universidade Federal do Vale do São Francisco (UNIVASF), 56300-000, Petrolina, PE, Brasil. E-mail: francine.hiromi@univasf.edu.br. "Corresponding author.

\begin{abstract}
The fungi Macrophomina phaseolina is the charcoal rot causal agent, one of the most important cowpea crop disease in semiarid regions can causes $100 \%$ yield losses. The search for resistant genotypes requires efficient phenotyping. In addition, there is the problem of great variation in aggressiveness between isolates. This study aimed to 1) test three methods of inoculation in semiarid conditions, and 2) to evaluate the aggressiveness of isolates of M. phaseolina. In the first experiment carried out in greenhouse, the inoculations methods were evaluated, using two cowpea lines, three inoculation methods and three pathogen isolates. On the second experiment, fifteen M. phaseolina isolates were inoculated in one cultivar to evaluate their aggressiveness. By assessing the length of the lesions and the severity of the disease using an index, we identified the toothpick inoculation method as the most efficient. Toothpick method allowed to discriminate the genotypes and the aggressiveness of the pathogen.
\end{abstract}

Key words: charcoal rot, toothpick method, phenotyping, Vigna unguiculata (L) Walp, semiarid.

Métodos de inoculação e agressividade de isolados de Macrophomina phaseolina em feijão-caupi

RESUMO: O fungo Macrophomina phaseolina é o agente etiológico da podridão cinzenta do caule, uma das mais importantes doenças na cultura do feijão caupi em regiões semiáridas, podendo ocasionar perdas de 100\%. A busca por genótipos resistentes exige uma fenotipagem eficiente. Além disso tem o problema da grande variação na agressividade entre isolados. Este trabalho teve como objetivos 1) testar três metodologias de inoculação em condições semiáridas, e 2) avaliar a agressividade de isolados de M. phaseolina. No primeiro experimento, conduzido em ambiente protegido, avaliou-se metodologias de inoculação em duas linhagens de caupi, por três métodos de inoculação e três isolados do patógeno. No segundo experimento, 15 isolados de M. phaseolina foram inoculados em uma cultivar de caupi para avaliar a agressividade do patógeno. Pela avaliação do comprimento das lesões e da severidade da doença por meio de um índice, identificamos o método de inoculação por palito de dente mais eficiente pois permitiu discriminar os genótipos estudados e a agressividade do patógeno. Palavras-chave: podridão cinzenta do caule, Botryosphaeriaceae, severidade, fenotipagem, Vigna unguiculata $(L)$ Walp.

\section{INTRODUCTION}

Cowpea (Vigna unguiculata (L.) Walp) originates from the African continent, having great importance in several countries such as Nigeria, Niger, Burkina Fazo and United Republic of Tanzania (BOUKAR et al., 2017). Nigeria is the largest world producer with 2,577,393.32 tons (FAO 2018). In Brazil, culture is of great socioeconomic importance and there has been an increase in planted area in recent years (total of 1,302,800 ha) mainly in the states of Mato Grosso, Ceará, Bahia and Piauí. Total production of 638 thousand tons of cowpea in the last year (CONAB, 2020). However, the average yield of the crop is still low (490 kg.ha-1), and this is due to factors such as low use of technology and the occurrence of diseases, such as charcoal rot, caused by the fungus Macrophomina phaseolina (Tassi) Goid. This can be considered one of the most important diseases of this crop (BOUKAR et al., 2017).

Macrophomina is widely distributed in Brazil and worldwide and infects over 700 plant species (FARR \& ROSSMAN, 2020). In beans as cowpea, this disease causes lesions blackened along the root and stem, both in seedlings, as in adult plants. In seedlings, pre-emergent damping off is frequent due to infection in the cotyledons and hypocotyl. In adult plants, wilt is often observed in warmer hours,

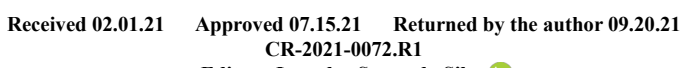


associated with the collapse of vascular bundles and plant death (YOU et al., 2011).

The primary and most important source of M. phaseolina's inoculum are microsclerotia, which are resistant long-lived structures that are usually formed during the pathogenic phase in infected cowpea tissues and in vitro conditions. The fungus can also penetrate through natural openings and through wounds (DHINGRA \& SINCLAIR, 1975; ZVEIBIL et al., 2012). The disease is favored by high temperatures, drought, and salinity of the soil, as is the case for other pathogens of the same family (PHILLIPS et al, 2013). These conditions are commonly reported in dryland cowpea crops in the Brazilian semiarid region.

The most rational strategy for disease control is the use of resistant cultivars. The use of chemical control is limited, as an inhabitant of the soil pathogen, not having much efficiency, in addition to environmental issues (MICHEREFF et al., 2005). However, there are few reports of cultivars with resistance to the disease and the information on inoculation methodologies and reaction evaluation are not consistent in this crop. This study aimed to 1) test three methods of inoculation in semiarid conditions, and 2) to evaluate the aggressiveness of isolates of M. phaseolina.

\section{MATERIALS AND METHODS}

Fifteen isolates of $M$. phaseolina were used (Table 1). Isolates were obtained from an infested area from the field of Agricultural Sciences Campus - Univasf $(16,24,59,60,80$ e JB01, JB03, JB04, JB05) Isolates with the initial letters CMM were obtained from the Phytopathogenic Fungal Culture Collection of Professor Maria Menezes from Federal Rural University of Pernambuco. Isolates N102 and N105 were obtained from the production area in the irrigation project Nilo Coelho, Petrolina, Pernambuco. Indirect isolation of the fungus was carried out in PDA (Potato Dextrose Agar) culture medium. Seven days after isolation, the hyphae tip methodology was used to obtain pure culture of $M$. phaseolina isolates.

Two cowpea cultivars, Canapú and Bicode-ouro were used in the first experiment. In the second experiment it was used only the Bico-deouro due number of seeds available. One seeds of each cowpea line were sown in plastic pots $(0.3 \mathrm{~L})$ containing commercial substrate. The sowing was done in greenhouse underscreens (Sombrite ${ }^{\circledR}$ ), which retained $50 \%$ brightness. After sowing, the pots were irrigated daily until inoculation. After inoculation, the pots were irrigated once a day with a fixed volume of $100 \mathrm{ml}$ of water.

\section{Inoculations methods}

The M. phaseolina isolates 80, CMM2106, and CMM2684 were obtain from different host species and were selected as inoculation source in the first experiment (Table 1). The substrate infestation method with rice grains colonized by the pathogen was carried out by cultivation of five $5 \mathrm{~mm}$ diameter discs from each of the three isolates of M. phaseolina in PDA medium plate (OLADIMEJI et al, 2012). The three isolates and the control (PDA medium disks without fungus) were transferred, independently, to $50 \mathrm{~mL}$ Erlenmeyer containing $15 \mathrm{~g}$ rice grains previously moistened with $5 \mathrm{~mL}$ of deionized water and autoclaved for 20 minutes. Culture maintained in a biological oxygen demand (BOD) at $25{ }^{\circ} \mathrm{C}$ for 15 days. After this period, colonized three grains of rice from each isolate were inoculated with three seeds from each line.

In the method of cut-stem, a disk of $5 \mathrm{~mm}$ in diameter from each isolate was transferred to Petri dishes containing PDA and incubated in a BOD for five days without photoperiod at $25^{\circ} \mathrm{C}$. On greenhouse, plants 20 days after emergence (DAE) had the petiole apparently more turgid from the upper extremity cut with the aid of scissors, the wound being covered with an autoclaved $10 \mu \mathrm{L}$ tip containing a $5 \mathrm{~mm}$ mycelium disc from each isolate. BDA medium disc without fungus was used as control (TWIZEYIMANA et al., 2012). The third method has the stem inoculation method with drilling toothpick colonized by the pathogen, as performed by COHEN et al (2016). The plants were inoculated at 20 DAE.

The experimental design was a completely randomized design (CRD), with 5 replicates in $2 \times 3 \times 2$ factorial scheme. The first factor consisted of two cowpea lines, Canapú and Bico-de-ouro, the second the inoculation methods and the last factor the isolates 80, CMM2106 and CMM2684, obtained from host plants of common beans, cowpea, and melon, respectively.

\section{Aggressiveness of M. phaseolina isolates.}

The aggressiveness of $M$. phaseolina isolates was evaluated in the cultivar 'Bico de Ouro' in a second experiment. A completely randomized design (CRD) was used, with the treatments consisting of the isolates described in table 1 plus the control (without fungus). Five repetitions per treatment were used. The inoculation method used in this experiment was infested toothpick (COHEN et al., 2016). 
Table 1 - Macrophomina phaseolina isolate used in this study, county and host plant of origin.

\begin{tabular}{|c|c|c|}
\hline Isolate & ----County----- & ---Host plant--- \\
\hline CMM2061 & Mossoró-RN & Melon \\
\hline CMM2106 & Teresina-PI & Cowpea \\
\hline CMM2684 & Baraúna-RN & Melon \\
\hline CMM2700 & Quixeré-CE & Melon \\
\hline JB01 & Petrolina-PE & Common bean \\
\hline JB03 & Petrolina-PE & Common bean \\
\hline JB04 & Petrolina-PE & Common bean \\
\hline JB05 & Petrolina-PE & Common bean \\
\hline N102 & Petrolina-PE & Cowpea \\
\hline N105 & Petrolina-PE & Cowpea \\
\hline 16 & Petrolina-PE & Common bean \\
\hline 24 & Petrolina-PE & Common bean \\
\hline 59 & Petrolina-PE & Common bean \\
\hline 60 & Petrolina-PE & Common bean \\
\hline 80 & Petrolina-PE & Common bean \\
\hline
\end{tabular}

\section{Data analysis}

The incidence, the lesion length and the severity estimated by an index were evaluated. In addition, using the severity data of the isolates, the Area Under the Disease Progress Curve (AUDPC) was calculated using the CAMPBELL \& MADDEN equation (1990). The lesion length and plant height were measured with the aid of millimeter ruler. The index was calculated by dividing the lesion length by plant height and multiplying by one hundred (\%). The incidence was calculated by dividing the number of sick plants by the total of plants inoculated and multiplied by one hundred. The evaluations were performed every two days, starting on the day of inoculation to evaluate the plant height, and ending with the appearance of the first dead plants at 6 days after inoculation. The results were subjected to analysis of variance and the means grouped by the Scott-knott test at 5\% significance, in the SISVAR 5.6 software. (FERREIRA, 2011). In the case of severity and AUDPC because the data did not meet the assumptions of the analysis of variance, they were subjected to the Kruskall-Wallis nonparametric test at $5 \%$ significance in the MINITAB14 software.

\section{RESULTS AND DISCUSSION}

The appearance of necrotic lesions occurred 2 days after inoculation for the methods of the toothpick and the cut-stem for both lines. However, for the infested substrate method, lesions were observed only 6 days after inoculation. The witnesses showed no injuries and were not used for statistical analyses. Regarding the incidence, values of $100 \%$ were obtained for the toothpick and cutstem methods, and $7.5 \%$ for the infested substrate method. This low incidence using the infested substrate inoculation method was also observed by MEDEIROS et al (2015) in melon. Probably, it will necessary longer time for evaluation when the infested substrate method is used. In the other methods tested, as inoculum is inserted directly into the host, a few days after inoculation it is possible to assess symptoms (COHEN et al., 2016; TWIZEYIMANA et al., 2012).

ISHIKAWA et al (2018) evaluated the reaction of seven soybean lines to charcoal rot by the methods of inoculation of the cut-stem, colonized toothpick, soil infested by inoculum produced in rice and irrigation with suspension of micro-sclerotia (3 $\times 10^{4}$ and $6 \times 10^{4} \mathrm{UFC} / \mathrm{mL}$ ) on seedling roots. It was observed that the cut-stem and colonized toothpick method caused the highest severity in the inoculated soybean plants. TWIZEYIMANA et al., (2012) also described the cut-stem method as efficient in the evaluation of soybean genotypes and in the evaluation of the aggressiveness of the pathogen isolates. Considering the low incidence of the disease 
in the infested rice method, statistical analyzes were performed considering only the other two methods.

In experiment 1 , for the lesion length, there was significant interaction method $\mathrm{x}$ cultivar (Figure $1 \mathrm{~A})$, and method $\mathrm{x}$ isolate (Figure 1B). The toothpick inoculation method was the most aggressive for both cv. Canapú and Bico de Ouro, presenting lesions length of $6.42 \mathrm{~cm}$ and $5.15 \mathrm{~cm}$; respectively, being about 4 times longer than the inoculation method of cut-stem (Figure 1A). When we compared the plant height difference, that is height in last day of evaluation less plant height at day of inoculation, there was a significant difference between the inoculation methods $(\mathrm{P}<0.05)$. For toothpick inoculation method average height difference was $0.995 \mathrm{~cm}$ and for cutstem method average were $2.135 \mathrm{~cm}$. Thus, toothpick inoculation method showed reducing of the growth of the inoculated plants by more than twice compared to the cut-stem method.

The lower efficiency of the stem-cut method in cowpea lines may be associated with the dehydration of the mycelium disc after inoculation of the petiole in semiarid conditions. This is important in studies that assess the effect of temperature on the severity of the disease, such as that carried out by LINHARES et al. (2020), who used the toothpick method and inoculated an $M$. phaseolina isolate in different varieties of melon under different temperatures. The higher the temperature and the lower the relative humidity of the air, the greater the chances of the mycelium disk dehydrating and failure in inoculation. Conversely, the greater aggressiveness of the toothpick method is due to the toothpick colonized by the pathogen directly reaching the conducting vessels of the host (MEDEIROS et al, 2015).

In the toothpick inoculation method, it was possible to observe a difference in the aggressiveness of the isolates, with isolate CMM2106 being the most aggressive, followed by isolate 80 and lastly, isolate CMM2684 (Figure 1B). There was no difference in the aggressiveness of isolates for cut-stem method (Figure 1B).

In the second experiment, the evaluation of the aggressiveness of the fifteen isolates showed an incidence greater than $90 \%$ in the inoculated plants. There was a statistical difference only for the lesion length. The values lesion length varied between 1.81 and $8.86 \mathrm{~cm}$, and isolates 16, 24, 59, CMM2106 and CMM2700 were statistically equal and caused the longest lesion lengths ranging from 4.98 to 8.86 $\mathrm{cm}$ (Figure 2). The other isolates formed the other group and did not differ statistically from each other; however, they caused lesions with an average length of $2.81 \mathrm{~cm}$, about twice less than that caused by the group of the most aggressive isolates. The severity of the disease based on the injury index in relation to the height of cowpea plants varied between 13.74 and $59.52 \%$. For severity and AUSCP, errors did not

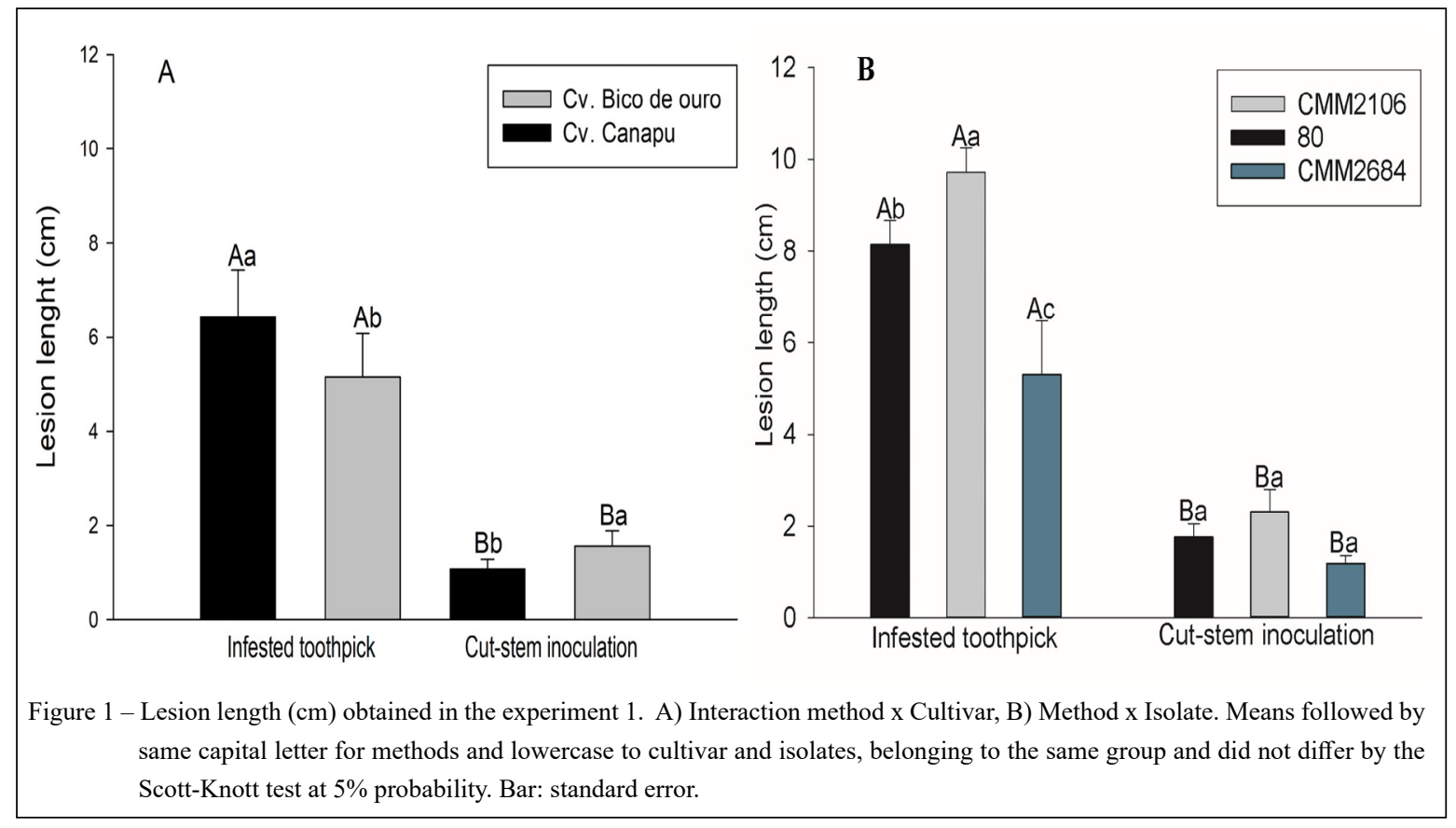

Ciência Rural, v.52, n.6, 2022. 


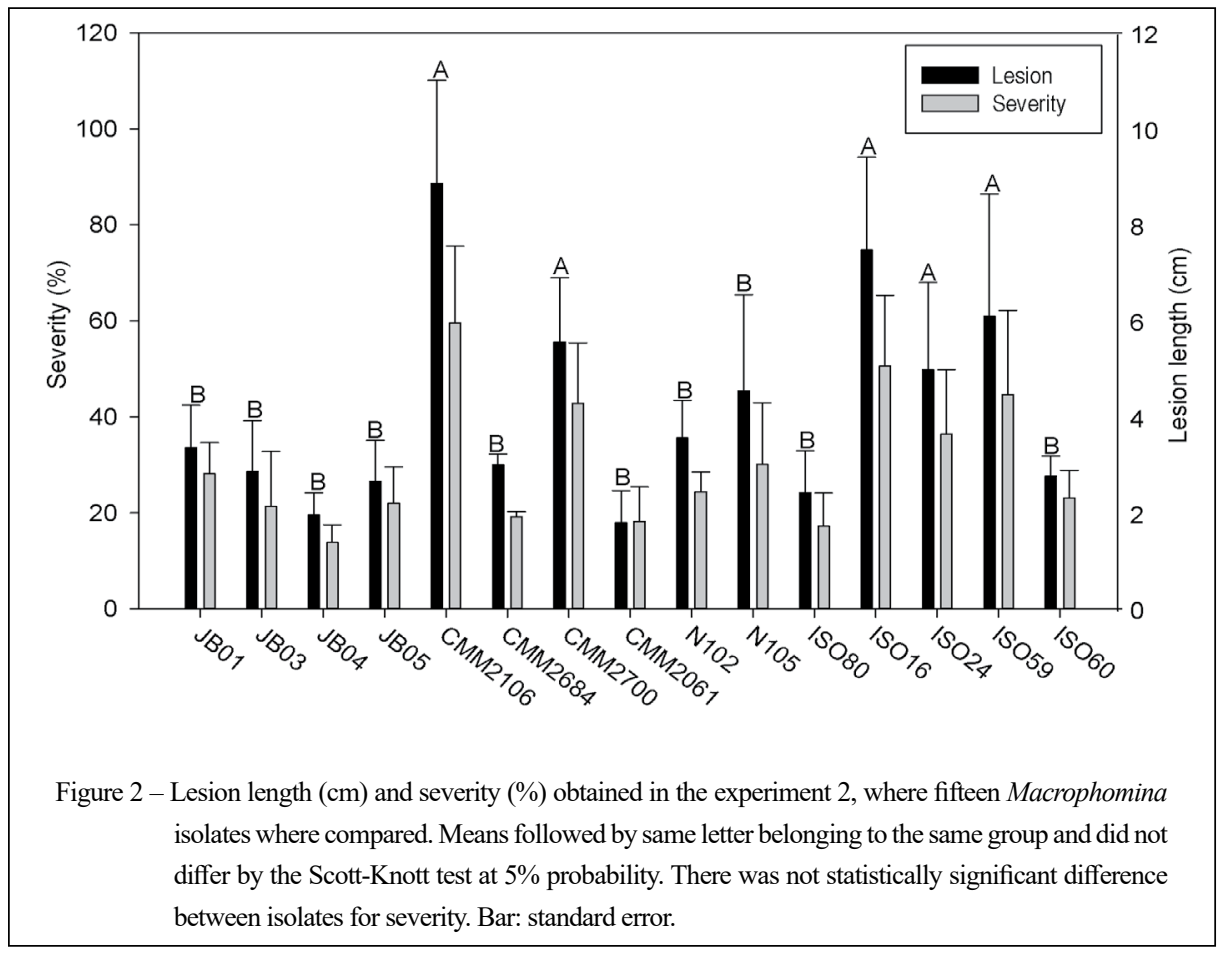

adjust normality, by Kruskal-Wallis test there was not a statistically significant difference between isolates for severity $(\mathrm{P}=0.17)$ and AUDCP $(\mathrm{P}=0.179)$.

NEGREIROS et al. (2020) evaluated the aggressiveness of different isolates of $M$. pseudophaseolina inoculated in melon and watermelon seedlings using the toothpick method. The method allowed to detect a difference in aggressiveness between the isolates and to re-isolate them.

The most efficient method of inoculation should make it possible to assess the disease and identify the most resistant genotypes as well as distinguish the pathogen's aggressiveness. Thus, for cowpea crop, the toothpick method proved to be the most appropriate method of inoculation.

\section{CONCLUSION}

The colonized toothpick inoculation method was the most efficient for evaluating cowpea and allowed to differentiate the aggressiveness of the isolates, with isolates 16, 24, 59, CMM2106 and CMM2700 being the most aggressive.

\section{ACKNOWLEDGEMENTS}

This work was supported by Foundation for the Support of Science and Technology of Pernambuco (FACEPE) [a research fellowship for the first author]. Financed in part by the Coordenação de Aperfeiçoamento de Pessoal de Nível Superior - Brasil (CAPES) - Finance Code 001. The authors would like to thank the Professor Sami Jorge Michereff for the isolates from the Culture Collection of Phytopathogenic Fungi 'Prof. Maria Menezes' (CMM) from Universidade Federal Rural de Pernambuco.

\section{DECLARATION OF CONFLICT OF INTEREST}

The authors declare that they have no competing interests associated with the publication of this study.

\section{AUTHORS' CONTRIBUTIONS}

E.M.S.S: Data curation, Formal analysis, WritingOriginal draft preparation. F.A.C.P: Data curation, Formal analysis and graphs; F.H. I.: Supervision, Visualization, Writing-Reviewing and Editing. L.A.B.S., J.C.B.; A.S.C.: Writing-Reviewing and Editing. All authors critically revised the manuscript and approved of the final version.

\section{REFERENCES}

BOUKAR, O.; et al. Cowpea (Vigna unguiculata): genetics, genomics and breeding. Plant Breeding, v. 138, n. 4, p. 415-424, 2018. Avaliable from: <http://dx.doi.org/10.1111/pbr.12589>. Acessed: Oct. 9, 2020. doi: 10.1111/pbr.12589.

CAMPBELL, C. L.; MADDEN, L. V. Introduction to plant disease epidemiology. New York: John Wiley \& Sons, 1990.

Ciência Rural, v.52, n.6, 2022. 
532p. Avaliable from: <https://www.cabdirect.org/cabdirect/ abstract/19912305030>. Acessed: Aug. 10, 2020.

COHEN, R.; et al. Variation in the responses of melon and watermelon to Macrophomina phaseolina. Crop Protection, v. 85, p. 46-51, 2016. Available from: < $<$ https://doi.org/10.1016/j. cropro.2016.03.015>. Acessed: Oct. 9, 2020. doi: 10.1016/j. cropro.2016.03.015.

COMPANHIA NACIONAL DE ABASTECIMENTO (CONAB) Acompanhamento de safra brasileira de grãos, 2020. Available from: <https://www.conab.gov.br/info-agro/safras $>$. Accessed: May. 5, 2020.

DHINGRA, O. D.; SINCLAIR, J. B. An annotated bibliography of Macrophomina phaseolina 1905-1975. 244p, 1977. Available from: <https://www.cabdirect.org/cabdirect/ abstract/19771338867>. Acessed: Oct. 9, 2020.

FARR, D.F., \& ROSSMAN, A.Y. 2020. Fungal Databases, U.S. National Fungus Collections, ARS, USDA. Disponível em: $<$ https://nt.ars-grin.gov/fungaldatabases/>. Acessed: Sep. 2, 2020.

FAO - FOOD AND AGRICULTURE ORGANIZATION. Fao stats, 2018. Available from: <http://www.fao.org/faostat/en/\#data/ QC/visualize>. Accessed: May. 5, 2020.

FERREIRA, D. F. Sisvar: a computer statistical analysis system. Ciência agrotecnológica, v. 35, n. 6, p. 1039-1042, 2011. Available from: $\quad<$ https://doi.org/10.1590/S1413-70542011000600001>. Acessed: Oct. 9, 2020. doi: <https://doi.org/10.1590/S1413$70542011000600001>$.

ISHIKAWA, M. S. et al. Seleção de cultivares de soja para resistência à podridão negra da raiz (Macrophomina phaseolina). Summa phytopathologica, v. 44, n. 1, p. 38-44, 2018. Available from: $<$ https://doi.org/10.1590/0100-5405/178653>. Acessed: Oct. 9, 2020. doi: 10.1590/0100-5405/178653.

LINHARES, C. M. S.; et al. Effect of temperature on disease severity of charcoal rot of melons caused by Macrophomina phaseolina: implications for selection of resistance sources. European Journal of Plant Pathology, v. 158, n. 2, p. 431-441, 2020. Available from:
$<$ http://dx.doi.org/10.1007/s10658-020-02083-w>. Acessed: Oct. 9, 2020. doi: 10.1007/s10658-020-02083-w.

MEDEIROS, A. C.; et al. Métodos de inoculação de Rhizoctonia solani e Macrophomina phaseolina em meloeiro (Cucumis melo). Summa phytopathologica, v. 14, n. 4, p. 281-286, 2015. Available from: <http://dx.doi.org/10.1590/0100-5405/2083>. Acessed: Oct. 9, 2020. doi: 10.1590/0100-5405/2083.

MICHEREFF, S. J. et al. Ecologia e manejo de patógenos radiculares em solos tropicais. Recife: Universidade Federal Rural de Pernambuco, 2005. 398 p. Avaliable from: <https:// www.repository.ufrpe.br/bitstream/123456789/2399/1/livro patologiaemanejoradiculares.pdf $>$. Acessed: Oct. 9, 2020.

NEGREIROS, A. M. P.; et al. Characterization of adaptability components of Brazilian isolates of Macrophomina pseudophaseolina. Journal Of Phytopathology, v. 168, n. 7-8, p. 490-499, 2020. Available from: <http://dx.doi.org/10.1111/ jph.12927>. Acessed: Oct. 9, 2020. doi: 10.1111/jph.12927.

OLADIMEJI, A.; et al. Screening of cowpea genotypes for resistance to Macrophomina phaseolina infection using two methods of inoculation. Asian Journal of Plant Pathology, v.6, p. 13-18, 2012. Available from: <https://scialert.net/abstract /?doi=ajppaj.2012.13.18>. Acessed: Oct. 9, 2020. doi: 10.3923 / ajppaj.2012.13.18

TWIZEYIMANA, M. et al. A Cut-Stem Inoculation Technique to Evaluate Soybean for Resistance to Macrophomina phaseolina. Plant Disease, v. 96, n. 8, p. 1210-1215, 2012. Available from: $<$ https://doi.org/10.1094/PDIS-02-12-0126-RE >. Acessed: Oct. 9, 2020. doi: 10.1094/PDIS-02-12-0126-RE.

YOU, M. P.; et al. Salinity drives host reaction in Phaseolus vulgaris (common bean) to Macrophomina phaseolina. Functional Plant Biology, v. 38, n. 12, p. 984-992, 2011. Available from: $<$ https://doi.org/10.1071/FP11137>. Acessed: Oct. 9, 2020. doi: 10.1071/FP11137

ZVEIBIL, Aida et al. Survival, host-pathogen interaction, and management of Macrophomina phaseolina on strawberry in Israel. Plant Disease, v. 96, n. 2, p. 265-272, 2012. 